\title{
INTERNAL PROPORTIONS OF THE BODY COMPOSITION IN MEMBERS OF THE FEMALE NATIONAL TENNIS TEAM OF POLAND
}

\author{
Marina Jagiello ${ }^{1}$, Wladislaw Jagiello ${ }^{1,2}$ \\ Academy of Physical Education and Sport ${ }^{1}$, Gdansk, \\ The College of Computer Science ${ }^{2}$, Lodz, Poland
}

\begin{abstract}
Marina Jagiello. PhD in Physical Education. Assistant Professor in the Department of Sports Games, the Faculty of Physical Education at the Academy of Physical Education and Sport in Gdansk (Poland). Research interests - preparation of young and highly skilled athletes and scientific management of the training process in tennis.
\end{abstract}

\begin{abstract}
Contemporary anthropological research confirms the fact that body composition is one of the basic elements differentiating athletes from persons not practising sport. Among athletes representing various branches of sport there are also significant differences in their body composition. Internal proportions of the body composition of an athlete, or a selected group of athletes, is an especially important yet little researched issue of sports anthropology. This problem is still topical in sports games, especially in tennis. Therefore, the aim of the study was to determine internal proportions of the body composition of female tennis players from the Polish national team in comparison to persons who do not practice sport professionally.

The study involved female athletes of the Polish national tennis team $(n=10)$. The study was carried out in a training camp from 28 September to 9 October 2002 in Zakopane - Centre of Sports Preparation. Athletes'age was 16-20 $(18.1 \pm 1.4)$ years, and the training experience $8-12$ years $(10.5 \pm 1.8)$. The mean body height for the group members was $171.9 \pm 6.7 \mathrm{~cm}$ and the mean body mass $59.7 \pm 6.3 \mathrm{~kg}$.

The results of research by Piechaczek et al. (1996) constituted the reference point for the results of measurements of Polish tennis representatives. The authors studied 153 female students of Warsaw Technical University aged $20.2 \pm 1.09$ years. They were randomly chosen students of the first and the second year of various departments at this university. The mean body height of the students was $166.2 \pm 6.2 \mathrm{~cm}$ and the mean body mass $57.4 \pm 7.72 \mathrm{~kg}$.

Anthropometric measurements were taken using standard instruments (Drozdowski, 1998). The analysis involved 11 somatic features which determined three so-called factors of body composition: length $\left(m_{1}\right)$, stoutness $\left(m_{2}\right)$ and obesity $\left(m_{3}\right)$. The assessment of proportions of the body composition was made by means of Perkal's natural indices (1953) with Milicerowa's modifications (1956).

We determined the following: composition factors $(m)$, index of total body size $(M)$, internal proportions of the body composition, evenness of composition, the code of internal proportions; also the assessment of internal proportions of the body composition within each of the factors.

Taking into consideration the mean values of the studied somatic features in the control group and the comparative group we found differences in their body composition. The representatives of the Polish national tennis team showed substantially longer upper and lower limbs, and the body height was greater. They also had much greater forearm perimeter and shorter pelvic width.

As to the total body size, the tennis players slightly exceeded the students $(M=0.24)$. The total body size $(M)$ resulted from high values of length features $\left(m_{1}=1.01\right)$, low ones of stoutness $\left(m_{2}=-0.39\right)$ and medium ones of obesity $\left(m_{3}=0.1\right)$. The value of the intragroup variability index (harmony of composition) amounted to 1.4 and the code of internal proportions of tennis players' body composition - to 6-2-4.

The proportions of internal features of the stoutness index (natural indices of features within a factor) showed the advantage of the forearm perimeter (1.62) and elbow width (0.36). The knee width (-1.30) and pelvic width (-0.60) were disproportionate to the total value of this factor. The input of features characterizing the length factor was relatively proportional.
\end{abstract}

Keywords: tennis, training, body composition, internal proportions.

\section{INTRODUCTION}

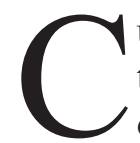
urrent studies of anthropologists confirm the fact that the body composition is one of the elements differentiating athletes from nonathletes (Drozdowski, 1998; Łaska-Mierzejewska, 1999). Significant differences in body composition are also observed among athletes engaged in different sports events (Tanner, 1964; Garay et al., 1974; Tittel, Wutscherk, 1991; Arnot, Gaines, 1992). 
There are studies aiming to reveal the dependence between various aspects of body composition and the level of sports mastery or efficiency of the competitive activity. These data are available for karate and judo (Sterkowicz, Żarów, 1988, 1994; Jagiello et al., 2004), Greco-Roman and free-style wrestling (Tumanian, Martirosow, 1976; Skład et al., 1995; Jagiełło W., Kruszewski 2005) pentathlon (Pacelt, 1992), track and field (Migasiewicz, 1999; Iskra, Walaszczyk, 2007), gymnastics (Drozdowski, 1984; Karosz,1993) and tennis (Jagiełło, Jagiełło, 2004).

These studies were based on the analysis of the so-called somatotypes, proportions or tissue components. In our opinion the question of internal proportions of the body composition of the given athlete or a selected group of athletes is a very important but insufficiently studied problem of sports anthropology. This problem is especially important in sports games, and tennis in particular.

Therefore, the aim of the study was to determine internal proportions of the body composition of female tennis players from the Polish national team in comparison to persons who do not practice sport professionally.

\section{RESEARCH SUBJECTS AND METHODS}

Ten female athletes, members of the national tennis team of Poland participated in the study. The study was conducted in a training camp from September 28 to October 9, 2002 in the city of Zakopane - the Centre of Sports Preparation. The female tennis players' age ranged from 16 to 20 years $(18.1 \pm 1.4)$, whereas their training experience was $8-12$ years $(10.5 \pm 1.8)$. The mean body height of the group was $171.9 \pm 6.7 \mathrm{~cm}$, and the mean body mass was $59.7 \pm 6.3 \mathrm{~kg}$. The results of the research by Piechaczek et al. (1996) constituted the reference point for the results of measurements of Polish tennis representatives. The authors studied 153 female students of Warsaw Technical University aged $20.2 \pm 1.09$ years. They were randomly chosen students of the first and the second year of various departments at this university. The mean body height for the students was $166.2 \pm 6.2 \mathrm{~cm}$ and the mean body mass $57.4 \pm 7.72 \mathrm{~kg}$.

Anthropometric measurements were conducted using standard instruments (Drozdowski, 1998).

Measurements of 11 anthropometric features were taken to determine three so-called factors of body composition: length $\left(\mathrm{m}_{1}\right)$, stoutness $\left(\mathrm{m}_{2}\right)$ and obesity $\left(\mathrm{m}_{3}\right)$. In this work factors of composition mean the features common to several indices in contrast to the notion of a factor as the cause of the appearance of a certain phenomenon or the formation of features.

In order to determine internal proportions of the body composition in members of female national tennis team of Poland the mathematical method of natural indices (Perkal, 1953) was used. The indices were calculated on the basis of standardized values $(Z)$ which are called standardized indices in statistics. A group of female students at Warsaw Technical University (Piechaczek et al., 1996) was used for standardization. Numerous scientific publications (Skibińska et al., 1987; Piechaczek et al., 1996) emphasize special comparative values of this social group in the studies on Polish athletes' body composition. The female students of the Technical University are characterised by the greatest biological development (height and body mass) among Polish academic youth. Thus they are the part of student population which is constitutionally closest to athletes, but on the other hand the students mentioned above as a whole are characterised by low physical activity. Hence, in comparison to them, there is a possibility to accurately determine the effects of the influence of specific training stimuli on the organisms of athletes specialising in a particular sport or event. In the presented profiles of body composition, the so-called zero line shows the mean values of students' features while distances from this line measured by standard deviation inform about the difference of the body composition between students and athletes (identification of features characterising tennis players' body composition).

The next stage (after standardization) of revealing internal proportions was to determine:

- Composition factors $m$ - by summing up the standardized values within each factor and dividing the sum by the number of features identified in the given factor. The obesity factor is an exception and it is a standardized value of skin and fat folds: $\mathrm{Z}=\mathrm{m}_{3}$.

- Index of total body size of the group (M): $\mathrm{M}=\mathrm{m}_{1}+\mathrm{m}_{2}+\mathrm{m}_{3} / 3$.

- Assessment of internal proportions of the body composition made by calculating Perkal's natural indices for each composition factor: $\mathrm{m}_{1}-\mathrm{M} ; \mathrm{m}_{2}-\mathrm{M} ; \mathrm{m}_{3}-\mathrm{M}$.

- Evenness of the composition was determined by means of the intrapersonal (intragroup) va- 
Table 1. Scale of points of Perkal's (1953) natural indices

\begin{tabular}{|c|ccc|l|}
\hline \multirow{2}{*}{ Points } & \multicolumn{4}{|c|}{ Values of natural indices } \\
\hline 1 & $\mathrm{X}$ & do & -1.07 & \\
2 & -1.06 & do & -0.57 & Below average \\
3 & -0.56 & do & -0.18 & \\
\cline { 2 - 4 } & -0.19 & do & 0.18 & Average \\
\cline { 4 - 5 } 5 & 0.19 & do & 0.57 & \\
6 & 0.58 & do & 1.06 & Above average \\
7 & 1.07 & do & $\mathrm{X}$ & \\
\hline
\end{tabular}

riability index - the difference between the natural index with the highest numerical value and the natural index with the lowest one.

- The code of internal proportions of the group on the basis of the point scale of Perkal's natural indices (Table 1). Natural indices have three-digit values and can be positive or negative. To bring them to one-digit values and free them of algebraic signs, these indicators are given values on the scale from 1 to 7 .

- The assessment of internal proportions of the body composition within each of the factors was made by taking away the value of the $m$ factor from the standardized feature.

\section{RESEARCH RESULTS}

Results of standardization of somatic indices of female tennis players showed the differences in the composition of their bodies as compared to the reference group (Table 2). The greatest differences were observed in the knee width, the upper and the lower extremity length and the forearm perimeter. These results show general properties of the body composition, yet they do not provide information on its internal proportions. Hence, the mathematical method of Perkal's natural indices (1953) was used.

Values of the body composition factors confirm the results obtained during the standardization of particular indices (Table 3 ) by more generalized means. The length factor $\left(\mathrm{m}_{1}=1.01\right)$ was the factor distinctly characterizing female tennis players' body composition.

The factor of stoutness (of skeleton and muscular tissue $-\mathrm{m}_{2}$ ) which constituted 0.39 as well as the index of total body size (M) which constituted 0.24 were slightly lower compared to the reference group. The factor of obesity $\left(\mathrm{m}_{3}=0.1\right)$ was the closest to that of the reference group.

The analysis of mutual proportions between factors of female tennis players' body composition demonstrated distinct differences in particular groups of composition indices (Table 4).
Table 2. Standardized anthropometric indices of the members of female national tennis team of Poland $(\mathbf{n}=\mathbf{1 0})$
Table 3. Factors of the body composition in members of female national tennis team of Poland $(n=10)$

\begin{tabular}{|c|c|c|c|c|c|c|}
\hline \multirow[t]{2}{*}{ Factors } & \multirow{2}{*}{\multicolumn{2}{|c|}{ Somatic features }} & \multicolumn{2}{|c|}{$\begin{array}{c}\text { Reference } \\
\text { group, } n=153\end{array}$} & \multirow{2}{*}{$\begin{array}{c}\begin{array}{c}\text { Female tennis } \\
\text { players, } n=10\end{array} \\
x\end{array}$} & \multirow{2}{*}{$\begin{array}{c}\begin{array}{c}\text { Standardized } \\
\text { value }\end{array} \\
\mathrm{Z} \\
\end{array}$} \\
\hline & & & $\mathbf{x}$ & SD & & \\
\hline \multirow{4}{*}{$\begin{array}{l}\mathrm{m}_{1} \\
\text { length }\end{array}$} & 1 & Body length, $\mathrm{cm}$ & 166.23 & 6.2 & 171.85 & 0.91 \\
\hline & 2 & Sitting body length, cm & 88.1 & 3.18 & 90.50 & 0.75 \\
\hline & 3 & $\begin{array}{l}\text { Upper extremity length, } \\
\mathrm{cm}\end{array}$ & 70.67 & 3.2 & 74.08 & 1.07 \\
\hline & 4 & $\begin{array}{l}\text { Lower extremity length, } \\
\mathrm{cm}\end{array}$ & 78.14 & 4.09 & 83.58 & 1.33 \\
\hline \multirow{6}{*}{$\begin{array}{l}\mathrm{m}_{2} \\
\text { stoutness }\end{array}$} & 5 & Shoulder width, cm (a-a) & 35.96 & 1.62 & 35.14 & -0.51 \\
\hline & 6 & Pelvis width, cm (ic-ic) & 27.98 & 1.46 & 26.53 & -0.99 \\
\hline & 7 & Elbow width, cm & 6.01 & 0.3 & 6.00 & -0.03 \\
\hline & 8 & $\begin{array}{l}\text { Knee width, cm (epl- } \\
\text { epm) }\end{array}$ & 8.81 & 0.43 & 8.08 & -1.70 \\
\hline & 9 & Forearm perimeter, $\mathrm{cm}$ & 22.36 & 1.42 & 24.10 & 1.23 \\
\hline & 10 & Shin width, cm & 35.32 & 2.66 & 34.38 & -0.35 \\
\hline $\begin{array}{l}\mathrm{m}_{3} \\
\text { obesity }\end{array}$ & 11 & $\begin{array}{l}\text { Thickness of } 3 \text { skin and } \\
\text { fat folds }\end{array}$ & 42.5 & 15 & 43.95 & 0.10 \\
\hline
\end{tabular}

\begin{tabular}{|l|c|c|c|c|}
\hline Factors & Length $\mathbf{m}_{\mathbf{1}}$ & Stoutness $\mathbf{~}_{\mathbf{2}}$ & Obesity $\mathbf{~}_{\mathbf{3}}$ & Index of total size $\mathbf{M}$ \\
\hline Values & 1.01 & -0.39 & 0.1 & 0.24 \\
\hline
\end{tabular}




\begin{tabular}{|l|c|c|c|c|}
\hline Natural indices & Length & Stoutness & Obesity & Intragroup variability index \\
\hline Values & 0.77 & -0.63 & -0.14 & 1.4 \\
\hline
\end{tabular}

Table 4. Natural indices of factors of the body composition in members of female national tennis team of Poland $(n=10)$

\begin{tabular}{|c|c|c|c|c|c|c|c|c|c|c|}
\hline Factors & \multicolumn{4}{|c|}{ Length } & \multicolumn{6}{|c|}{ Stoutness } \\
\hline 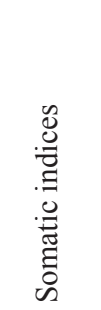 & 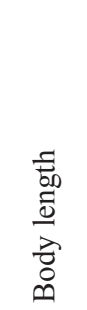 & 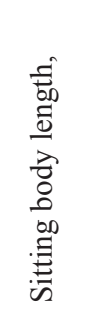 & 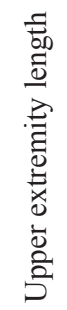 & 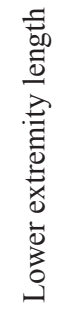 & 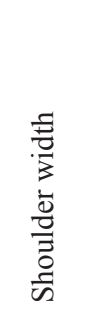 & $\begin{array}{l}\frac{5}{5} \\
\frac{0}{3} \\
\frac{n}{3} \\
0 \\
0\end{array}$ & 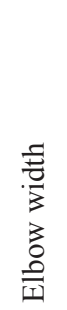 & 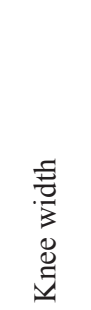 & 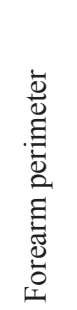 & 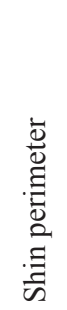 \\
\hline Values & -0.11 & -0.26 & 0.05 & 0.32 & -0.11 & -0.60 & 0.36 & -1.30 & 1.62 & 0.04 \\
\hline
\end{tabular}

Table 5. Natural indices of the somatic features within the factors in members of the female national tennis team of Poland $(\mathbf{n}=\mathbf{1 0})$

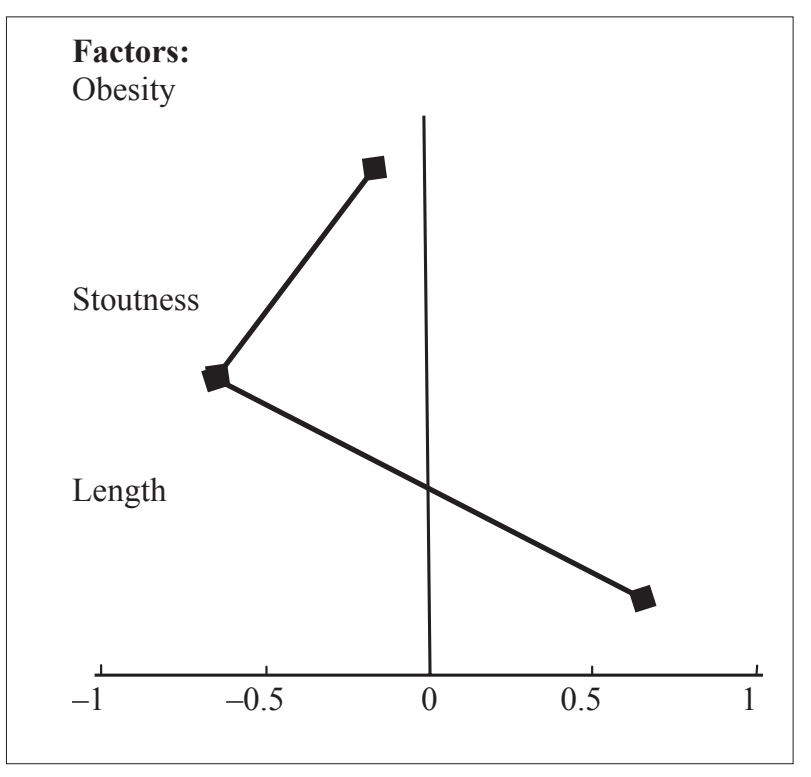

Fig. 1. Natural indices of factors of the body composition in members of the female national tennis team of Poland $(n=10)$

The value of intragroup variability index (composition uniformity) is rather high (1.4). The most distinctive feature of such composition is great length as well as proportional to the total body size low contribution of stoutness. Indices of obesity are most proportional to the total body size (Fig. 1).

The code of internal proportions of the studied female tennis players $(6-2-4)$ was obtained on the basis of Perkal's (1953) scale. It means that the total body size (M) is related to higher longitudinal body dimensions, low stoutness and an average degree of obesity.

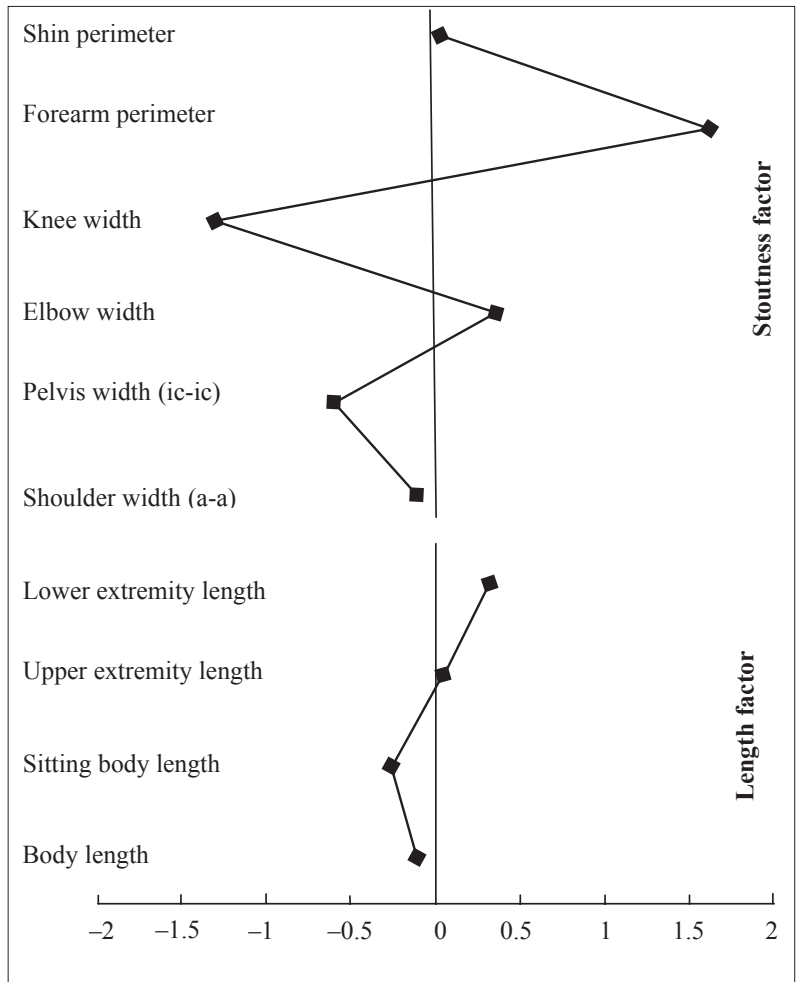

Fig. 2. Natural indices of the somatic features within the factors in the members of the female national tennis team of Poland $(\mathrm{n}=10)$

The analysis of internal proportions of the somatic features within the specified factors (natural indices of the somatic features within the factors) provides significant information on the tennis players' body composition. Natural indices of the somatic features within the factors were calculated by deducting the value of $\mathrm{m}$ factor from a standardized feature (Table 5).

In the indices identical to the stoutness factor a distinct prevalence of forearm perimeter (1.62) was revealed. Knee $(-1.30)$ and pelvis $(-0.60)$ widths were non-proportional to the total value of this factor. In length indices some advantage 
of the lower extremity length $(0.32)$ as compared to the sitting body length $(-0.26)$ was noted. The contribution of the body length and that of the upper extremity to the length factor were rather similar (Fig. 2).

\section{DISCUSSION}

Determining internal proportions of the body composition is particularly important in the studies on athletes. The applied Perkal's method (1953) with Milicerowa's modifications (1956) was created many years ago and is very laborious. However, due to multiple use of this method in the past it was possible to refer the results of our study to earlier research.

Among factors of the body composition just that of obesity was the closest to the control group. The greatest superiority of female tennis players was expressed in the length factor. In this regard it should be noted that the youth of the Warsaw Technical University is the most physically developed academic group of the population.

Analogous studies of the male national tennis team of Poland (Jagiełło W., Jagiełło M., 2006) demonstrated that the total body size (M) was the closest to the control group, whereas the highest superiority of athletes related to the length factor.

Presented indices of the body composition factors prove that in body composition of the members of the female national tennis team of Poland the leptosomic features prevail along with a high degree of index variability.

T. Łaska-Mierzejewska's studies (1999) on sports games confirmed this tendency - top level athletes are characterized by distinct superiority of one factor over another. Athletes of the national team of Poland have high values of the internal variability index, whereas in athletes of the third league (and especially in volleyball) they are close to zero.

The above regularity was mentioned by A. Claessens et al. (1986) in the examination of the body composition of female gymnasts at different skill levels. Female gymnasts are characterized by very lean body composition or low body mass relative to the body length. For elite female gymnasts more linear body composition is peculiar compared to those of the lowest skill level.

Natural indices of somatic indices within factors sufficiently identify tennis specifics. In the stoutness factor, for example, distinct superiority of the forearm perimeter and the elbow width as well as a relatively uniform contribution of length indices confirm the previously revealed adaptation peculiarities of loads in tennis (Jagiełł, 2005).

Proceeding from the obtained findings we can conclude that a mathematical method for the analysis of internal proportions of the body composition using natural indices (Perkal, 1953) is a rather prospective way for analysis and evaluation of these aspects. Unlike other methods of the body composition evaluation it has several advantages (Perkal, 1953; Milicerowa, 1956; Laska-Mierzejewska, 2002).

During standardization of anthropometric data we may receive the arithmetical mean of the studied group or the mean of the group of academic youth of Poland in our case. Thus, we get an answer to the question by which indices and at what level our athletes differ from the mean reference group, i.e., we may evaluate the impact of athletic preparation.

Other methods for body composition evaluation are usually orientated to certain biological-geographical and socio-economic life conditions as, for instance, it is the case of American university youth in Sheldon's somatotyping (Sheldon, 1940). These the so-called exogamous factors are (together with endogamous ones) the major factors of human development (Wolański, 2005). Therefore, in order to determine the body composition peculiarities, it is advisable to use the reference group meeting the life conditions of the studied contingent.

\section{CONCLUSIONS}

1. Taking into consideration the mean values of the studied somatic features in the control group and the reference group we can find differences in their body composition. The representatives of the Polish national tennis team are characterized by substantial lengths of upper and lower limbs and the body height. They also have much longer forearm perimeter and shorter pelvic width. Thus they represent a leptosomatic type of body composition.

2. Female tennis players do not differ significantly from students not engaged in sports training according to the total body size $(\mathrm{M}=0.24)$. However, they are characterized by a higher length factor $\left(\mathrm{m}_{1}=1.01\right)$ along with a low value of stoutness $\left(\mathrm{m}_{1}=-0.39\right)$. 
3. Natural indices of the body composition factors indicate internal proportions of female tennis players $(6-2-4)$ in which the total body size is due to high longitudinal body dimensions (6), low indices of stoutness (2) and an average degree of obesity (4).
4. Natural indices of features within the stoutness factor revealed the prevalence of the forearm perimeter (1.62) and elbow width (0.36). The knee width $(-1.30)$ and pelvis width $(-0.60)$ are disproportionate to the overall value of his factor. The input of features characterizing the length factor is relatively proportional.

\section{REFERENCES}

Arnot, R., Gaines, C. (1992). Tratado de la actividad fisica. Seleccione su deporte. Barcelona: Scientific Publications. P. 285-289.

Claessens, A. et al. (1986). Body structure, somatotype and motor fitness of top-class Belgia judoists and karateka: A comparative study. In T. Reilly, J. Watkins, J. Borms (Eds.), Kinanthropometry III. London: Spon. P. 53.

Drozdowski, Z. (1984). Aktualny stan badań morfologicznych uwarunkowań powodzenia $w$ gimnastyce $i$ akrobatyce. Poznań: AWF.

Drozdowski, Z. (1998). Antropometria $w$ wychowaniu fizycznym. AWF w Poznaniu. Seria: Podręczniki No 24.

Garay, A. L., Levine, L., Carter, J. E. I. (1974). Genetic and Anthropological Studies of Olympic Athletes. New York-San Francisco-London: Academic Press.

Iskra, J., Walaszczyk, A. (2007). Somatic build type and 110-m male hurdler training specificity. Research Yearbook. Studies in Physical Education and Sport, 13 (1), $122-125$.

Jagiełło, M., Jagiełło, W. (2004). Somatic changes in Polish representatives of tennis in the annual training period. In J. Szopa, T. Gabryś (Eds.), Sport Training in Interdisciplinary Scientific Researches. Czestochowa. P. $193-200$.

Jagiełło, M. (2005). Profil strojenia tela żenskoj sbornoj komandy Polszi po tennisu. Pedagogika, psychologia ta mediko-biologiczne problemy fizycznego wychowania $i$ sportu, 23, 135-139.

Jagiełło, W., Jagiełło, M. (2006). Wnutriennyje proporcje strojenia tela czlenow myzskoj sbornoj Polszi po tennisu. Pedagogika, psychologia ta mediko-biologiczne problemy fizycznego wychowania i sportu, 5, 141-145.

Jagiełło, W., Kalina, R., Korobielnikow, G. (2007). Morphological diversification of female judo athletes. Archives of Budo, 3, 27-34.

Jagiełło, W., Kruszewski, A. (2005). Morfologiczne aspekty poziomu sportowego zawodniczek uprawiających zapasy. W A. Kuder, K. Perkowski, D. Śledziewski (red.), Proces doskonalenia treningu $i$ walki sportowej. Tom 2, rozdział 2.7, s. 98-100. Warszawa.

Jagiełło, W., Tkaczuk, W., Jasiński, T. (2004). Somatic development of children in the process of long-term training in judo. Ugdymas. Küno kultūra. Sportas, 4 (54), 59-65.

Karosz, K. (1993). Sprawność fizyczna i budowa ciała dziewcząt i chłopców rozpoczynających uprawianie gimnastyki. Zeszyty Metodyczno-Naukowe AWF Katowice, 2, $215-224$
Łaska-Mierzejewska, T. (1999). Antropologia w sporcie $i$ wychowaniu Fizycznym: Biblioteka Trenera. Warszawa: Centralny Ośrodek Sportu.

Łaska-Mierzejewska, T. (Red.). (2002). Ćwiczenia z antropologii. Warszawa: Akademia Wychowania Fizycznego Józefa Piłsudskiego.

Migasiewicz, J. (1999). Zróżnicowanie dymorficzne wybranych cech morfologicznych kobiet i mężczyzn uprawiających rzut dyskiem. Wychowania Fizyczne i Sport, $3,111-120$

Milicerowa, H. (1956). Zastosowanie wskaźników Perkala do charakterystyki budowy ciała bokserów. Materiały $i$ Prace Antropologiczne, 20.

Pacelt, B. (1992). Zmiany komponentów tkankowych ciała pięcioboistów w cyklu treningowym: Praca doktorska. Warszawa: AWF.

Perkal, J. (1953). O wskaźnikach antropologicznych. Przeglad Antropologiczny, 19, 209-211.

Piechaczek, H., Lewandowska, J., Orlicz, B. (1996). Zmiany w budowie ciała młodzieży akademickiej Politechniki Warszawskiej w okresie 35 lat. Wychowanie Fizyczne $i$ Sport, 3, 3-14.

Sheldon, W. H. (1940). The Varieties of Human Physique. New Jork: Harper.

Skibińska, A., Łaska-Mierzejewska, T., Piechaczek, H. (1987). Typologia budowy ciała studentów Politechniki Warszawskiej. Wychowanie Fizyczne i Sport, 3, 43-50.

Skład, M., Krawczyk, B., Majle, B. (1995). Body build factors and body components in Greco-Roman and freestyle wrestlers. Biology of Sport, 2, 101-105.

Sterkowicz, S., Żarów, R. (1988). Charakterystyka budowy somatycznej karateków. Wychowanie Fizyczne i Sport, 4, $69-77$.

Sterkowicz, S., Żarów, R. (1994). Charakterystyka budowy somatycznej zawodniczek karate. Wychowanie Fizyczne $i$ Sport, 3, 33-41.

Tanner, J. M. (1964). The Physique of the Olympic Athlete. London.

Tittel, K., Wutscherk, H. (1991). Anthropometric Factors. Strengh and Power in Sport. Blackwell Scientific Publications, 180-196.

Tumanian, G. C., Martirosow, E. G. (1976). Tiełosłożenie $i$ sport. Moskwa: Fizkultura i sport.

Wolański, N. (2005). Rozwój biologiczny człowieka. Warszawa: PWN 


\title{
LENKIJOS MOTERŲ TENISO RINKTINĖS NARIŲ KŪNO SANDAROS PROPORCIJOS
}

\author{
Marina Jagiello ${ }^{1}$, Wladislaw Jagiello ${ }^{2}$ \\ Gdansko kūno kultūros ir sporto akademija ${ }^{1}$, Gdanskas, \\ Lodzès kompiuteriu mokslo kolegija ${ }^{2}$, Lodzè, Lenkija
}

\section{SANTRAUKA}

Šiuolaikiniai antropologiniai tyrimai patvirtina faktą, kad sportininkų ir nesportuojančių asmenų, skirtingų šakų sportininkų kūno sandara skiriasi. Sportininko ar tam tikros sportininkų grupès kūno proporcijos yra labai svarbi, tačiau mažai tyrinèta sporto antropologijos problema. Ši problema labai aktuali sportinių žaidimų, ypač teniso srityje. Taigi tyrimo tikslas - nustatyti Lenkijos moterų teniso rinktinès narių kūno sandaros proporcijas, lyginant su moterimis, kurios profesionaliai nesportuoja.

Buvo tiriamos Lenkijos rinktinès teniso komandos narès $(n=10)$. Tyrimas vyko treniruočių stovykloje nuo $2002 \mathrm{~m}$. rugsèjo 28 iki spalio 9 dienos Zakopanès sportinio rengimo centre. Sportininkių amžius 16 -20 metų $(18,1 \pm 1,4)$, treniravimosi trukmè $-8-12$ metų $(10,5 \pm 1,8)$. Grupés narių vidutinis ūgis $171,9 \pm 6,7 \mathrm{~cm}$, vidutinè kūno masè $-59,7 \pm 6,3 \mathrm{~kg}$.

Lenkijos tenisininkių kūno matmenys palyginti su H. Piechaczek ir kolegu (1996) gautaisiais. Autoriai buvo ištyrę 153 Varšuvos technikos universiteto studentes, kurių amžius - 20,2 $\pm 1,09$ metų. Šios pirmo ir antro kurso îvairių fakultetų studentès buvo atrinktos atsitiktiniu būdu. Studenčių vidutinis ūgis $166,2 \pm 6,2 \mathrm{~cm}$, kūno masè $-57,4 \pm 7,72 \mathrm{~kg}$.

Antropometriniai matavimai atlikti naudojant standartinius būdus (Drozdowsi, 1998). Buvo analizuojama 11 somatinių savybių, kurios apibūdino tris kūno sandaros dydžius: ilgi $\left(\mathrm{m}_{1}\right)$, stambumą $\left(\mathrm{m}_{2}\right)$ ir nutukimą $\left(\mathrm{m}_{3}\right)$. Kūno sandaros proporcijos įvertintos pagal J. Perkal (1953) natūralius indeksus, kuriuos modifikavo H. Milicerowa (1956).

Nustatyti šie indeksai: sandaros dydžiai (m), viso kūno dydžio indeksas (M), kūno sandaros proporcijos, sandaros tolygumas, kūno proporcijų kodas. Kūno proporcijos buvo vertinamos kiekvienu iš šiu aspektų.

Vidutinès tirtu kūno sandaros somatinių savybių vertès kontrolinèje ir lyginamojoje grupejje skyrèsi. Lenkijos tenisininkių rinktinès narès išsiskyrè rankų ir kojų ilgiu, ūgiu. Jų dilbio perimetras buvo didesnis, o dubens plotis - mažesnis.

Kalbant apie bendrą kūno dydị, tenisininkių rodikliai buvo šiek tiek didesni nei studenčių $(M=0,24)$. Bendras kūno dydis $(M)$ priklausè nuo kūno dalių ilgio reikšmių $\left(\mathrm{m}_{1}=1,01\right)$, mažų kūno stambumo reikšmių $\left(\mathrm{m}_{2}=0,39\right)$ ir vidutinių nutukimo reikšmių $\left(\mathrm{m}_{3}=0,1\right)$. Kaitumo indekso grupės viduje reikšmè (kūno sandaros dermè (harmonija)) siekè 1,4, o kūno proporcijų kodas 6-2-4.

Stambumo indekso kūno savybių proporcijos (natūralių savybių indeksai faktoriaus viduje) parodè, kad yra dilbio perimetro $(1,62)$ ir alkūnès pločio $(0,36)$ pranašumas. Kelio plotis $(-1,30)$ ir dubens plotis $(-0,60)$ yra neproporcingi bendrai šio faktoriaus vertei. Savybės, apibūdinančios ilgio faktorių, yra sąlygiškai proporcingos.

Raktažodžiai: tenisas, treniravimasis, kūno sandara, kūno proporcijos.

Gauta 2008 m. balandžio 10 d.

Received on April 10, 2008 